\title{
Aplikasi Manajemen Servis Dan Penjualan Laptop Studi Kasus Sumedang Laptop
}

\author{
David Setiadi \\ Program Studi Teknik Informatika \\ STMIK Sumedang, Jl. Angkrek Situ No. 19, Sumedang, 45323 Indonesia \\ email : david@stmik-sumedangac.id
}

\begin{abstract}
Perkembangan teknologi komunikasi dan informasi pada saat ini sulit untuk dipisahkan dari kehidupan manusia, baik aktifitas individu maupun perusahaan sudah banyak yang bergatung pada beberapa produk teknologi informasi dan komunikasi. Vendor teknologi menjamur, ada yang bertahan dan tidak sedikit yang bangkrut akibat tidak dapat mengimbangi laju percepatan perkembangan teknologi saat ini. Dalam pengembangan aplikasi ini peneliti menggunakan model pendekatan SDLC (System Development Life Cycle) dengan model Prototyping karena aplikasi ini tidak terlalu besar dan komplek, juga dengan metode ini pembuatan aplikasi lebih cepat dan efisien untuk membangun sebuah sistem yang mampu mengelola pembukuan servis dan penjualan laptop di Sumedang Laptop untuk membantu pekerjaan admin dan teknisi dalam mengatur antrian, pencatatan kerusakan hingga jual beli laptop bekas
\end{abstract}

Kata Kunci : SDLC, Protyping, System, Manajemen, Aplikasi

\section{Introduction}

Perkembangan teknologi komunikasi dan informasi pada saat ini sulit untuk dipisahkan dari kehidupan manusia, baik aktifitas individu maupun perusahaan sudah banyak yang bergatung pada beberapa produk teknologi informasi dan komunikasi. Vendor teknologi menjamur, ada yang bertahan dan tidak sedikit yang bangkrut akibat tidak dapat mengimbangi laju percepatan perkembangan teknologi saat ini.

Beberapa produk yang saat ini sedang melaju pesat adalah produk smartpone dan notebook, salahsatunya adalah produk Asus yang mengklaim sudah menguasai 51,7\% pasar Notebook di indonesia pada kuartal IV tahun 2016 (menurut data IDC) atau sekitar 2,2 juta Notebook yang terjual di Indonesia, yang disusul vendor Acer dan vendor-vendor lainnya seperti, Lenovo, HP, Samsung, Dell, Apple dan lain-lain.

Keadaan ini berimbas pada jasa servis laptop dan penjualan laptop bekas, karena sifat dari barang elektronik yang mudah rusak maka sama halnya dengan Laptop, dari studi kasus yang diambil oleh peneliti yaitu Sumedang Laptop menunjukan bahwa servis laptop yang masuk ke sumedang laptop ratarata 26-35 Laptop perbulan. Dari mulai kerusakan ringan hingga berat, dari vendor terkenal hingga vendor biasa, dari harga diatas puluhan juta hingga dibawah harga 5 juta banyak keluar masuk. Kendala yang dihadapi adalah tidak semua laptop yang masuk bisa langsung diperbaiki, atau bisa diperbaiki dengan cepat, beberapa harus menunggu sparepart hingga berbulan-bulan, beberapa harus menunggu antrian yang panjang. Tanpa manajemen yang baik mangga beberapa antrian bisa terjadi kekacauan, dari mulai tanggal masuk sampai sorting berdasarkan tingkat kesulitan/ kerusakan laptop. Maka perlu dibuat sebuah sistem yang mampu mengelola pembukuan servis dan penjualan laptop di Sumedang Laptop untuk membantu pekerjaan admin dan teknisi dalam mengatur antrian, pencatatan kerusakan hingga jual beli laptop bekas 


\section{Research Method}

Dalam pengembangan aplikasi ini peneliti menggunakan model pendekatan SDLC (System Development Life Cycle) dengan model Prototyping karena aplikasi ini tidak terlalu besar dan komplek, juga dengan metode ini pembuatan aplikasi lebih cepat dan efisien. Langkah-langkah yang dilakukan peneliti dalam pembangunan sistem dengan metode ini adalah sebagai berikut :

1. Pengumpulan Kebutuhan, yaitu antara developer dan client bertemu untuk mengumpulkan informasi dan menentukan tujuan sistem yang akan dibuat sesuai dengan kebutuan client.

2. Perancangan, tahap ini dilakukan berdasarkan informasi yang didapat dari tahap sebelumnya dan dibuat menjadi rancangan sistem dan prototype.

3. Evaluasi Prototype, dari hasil implementasi atau prototyping sistem yang sudah berhasil dibangun dievaluasi kembali untuk menentukan progres sistem yang dibuat apakh perlu direvisi atau selesai.

Adapun metode pengumpulan data (kebutuhan)yang digunakan dalam penelitian ini adalah :

1. Metode dokumentasi yaitu pengumpulan data dimana peneliti menyelidiki benda-benda tertulis seperti buku-buku, majalah, dokumen, peraturan peraturan, dan sebagainya [4] . Metode ini digunakan untuk memperoleh data tentang jasa servis dan penjualan Laptop di Sumedang Laptop.

2. Metode Wawancara yaitu peneliti berkomunikasi langsung dengan Owner Sumedang Laptop untuk menggali informasi dan permasalahan yang ada di Sumedang Laptop.

\subsection{Desain Sistem}

Adapun desain sistem hardware yang disarankan untuk penelitian ini adalah digambarkan dibawah ini :

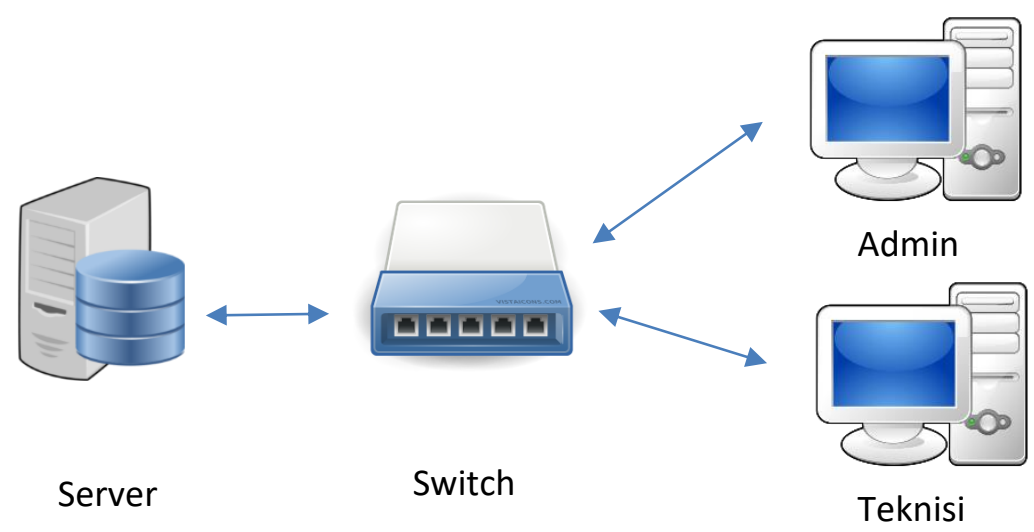

Gambar 2. Desain Sistem

Aplikasi didesain dengan web base sehingga dapat diakses oleh beberapa user sekaligus dalam satu jaringan, dimana user disini adalah admin toko yang menginput servis masuk yang kemudian diteruskan ke teknisi, kemudian teknisi dapat merubah status servisan selesai, pending atau cancel.

\section{Result and Analysis}

Pemodelan dilakukan untuk mendeskripsikan kebutuhan sistem dan spesifikasi sistem yang akan dibangun sehingga mudah untuk dilanjutkan ke tahap perncangan sistem.

\section{a. Usecase}




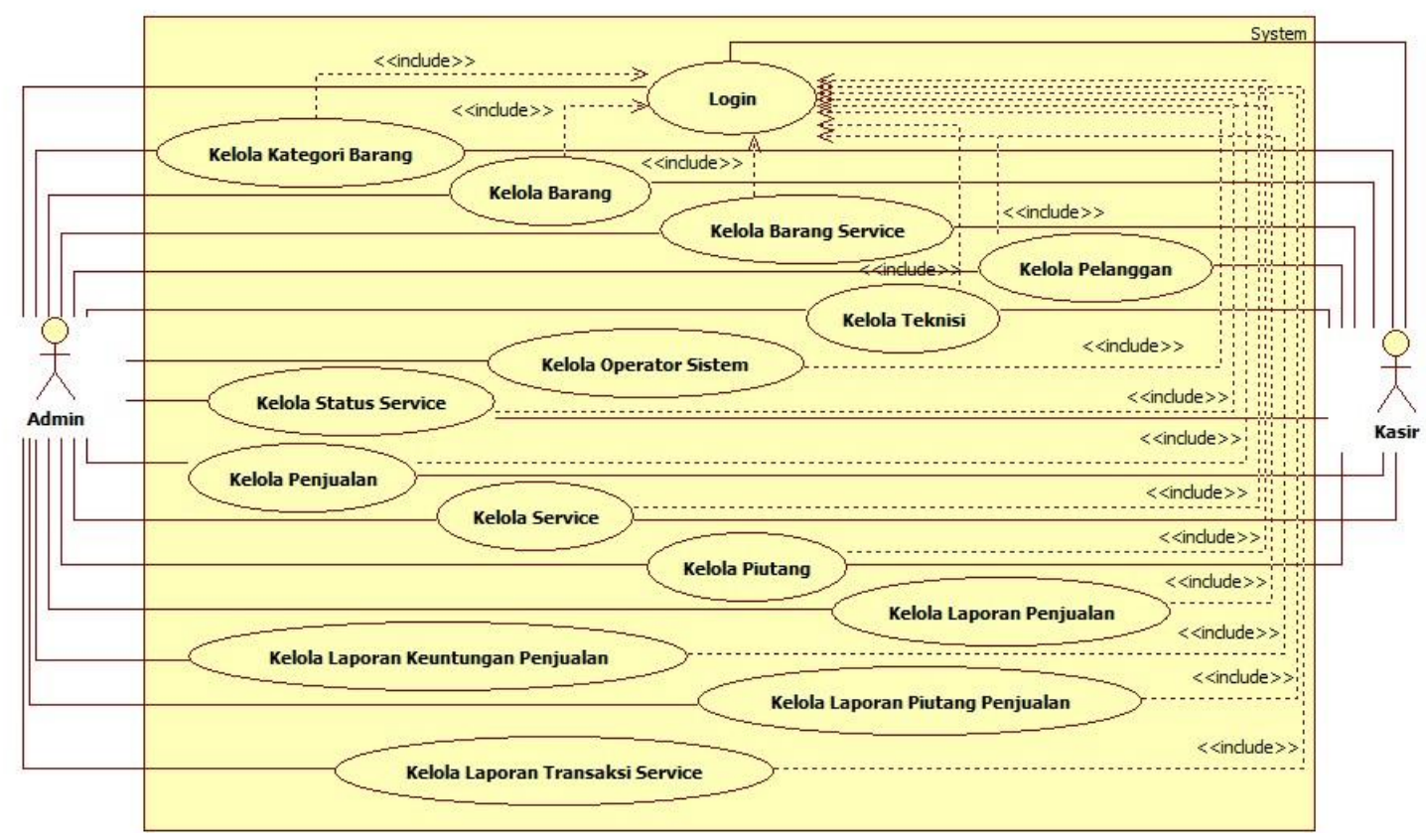

Gambar 2. Usecase Diagram

Definisi Aktor

Tabel 1. Definisi Aktor

\begin{tabular}{|c|l|l|}
\hline No & \multicolumn{1}{|c|}{ Aktor } & \multicolumn{1}{c|}{ Deskripsi } \\
\hline 1 & Admin & Pengguna sistem yang melakkukan seluruh proses yang ada di dalam sistem \\
\hline 2 & Kasir & $\begin{array}{l}\text { Pengguna sistem yang hanya dapat melakukan kelola data dan kelola transaksi tetapi } \\
\text { tidak bisa hapus serta edit data }\end{array}$ \\
\hline
\end{tabular}

\section{Definisi Usecase}

Tabel 2. Definisi Usecase

\begin{tabular}{|l|l|l|}
\hline No & \multicolumn{1}{|c|}{ Usecase } & \multicolumn{1}{c|}{ Deskripsi } \\
\hline 1 & Login & $\begin{array}{l}\text { Menggambarkan proses autentifikasi kepa user dalam } \\
\text { menjalanka user }\end{array}$ \\
\hline 2 & Kelola kategori barang & Menggambarkan proses mengelola data kategori barang \\
\hline 3 & Kelola barang & Menggambarkan proses mengelola data barang \\
\hline 4 & Kelola barang service & Menggambarkan proses mengelola data barang service \\
\hline 5 & Kelola pelanggan & Menggambarkan proses mengelola data Pelanggan \\
\hline 6 & Kelola teknis & Menggambarkan proses mengelola data teknis \\
\hline 7 & Kelola operator sistem & Menggambarkan proses mengelola data operator sistem \\
\hline 8 & Kelola status service & Menggambarkan proses mengelola data status service \\
\hline 9 & Kelola penjualan & Menggambarkan proses mengelola data penjualan \\
\hline 10 & Kelola service & Menggambarkan proses mengelola data service \\
\hline 11 & Kelola piutang & Menggambarkan proses mengelola data piutang \\
\hline 12 & Kelola Laporan penjualan & Menggambarkan proses mengelola Laporan penjualan \\
\hline 13 & Kelola Laporan transaksi service & Menggambarkan proses mengelola Laporan transaksi service \\
\hline 14 & Kelola Laporan keuntungan penjualan & $\begin{array}{l}\text { Menggambarkan proses mengelola Laporan keuntungan } \\
\text { penjualan }\end{array}$ \\
\hline 15 & Kelola Laporan piutang penjualan & Menggambarkan proses mengelola Laporan piutang penjualan \\
\hline
\end{tabular}




\section{a. Class Diagram}

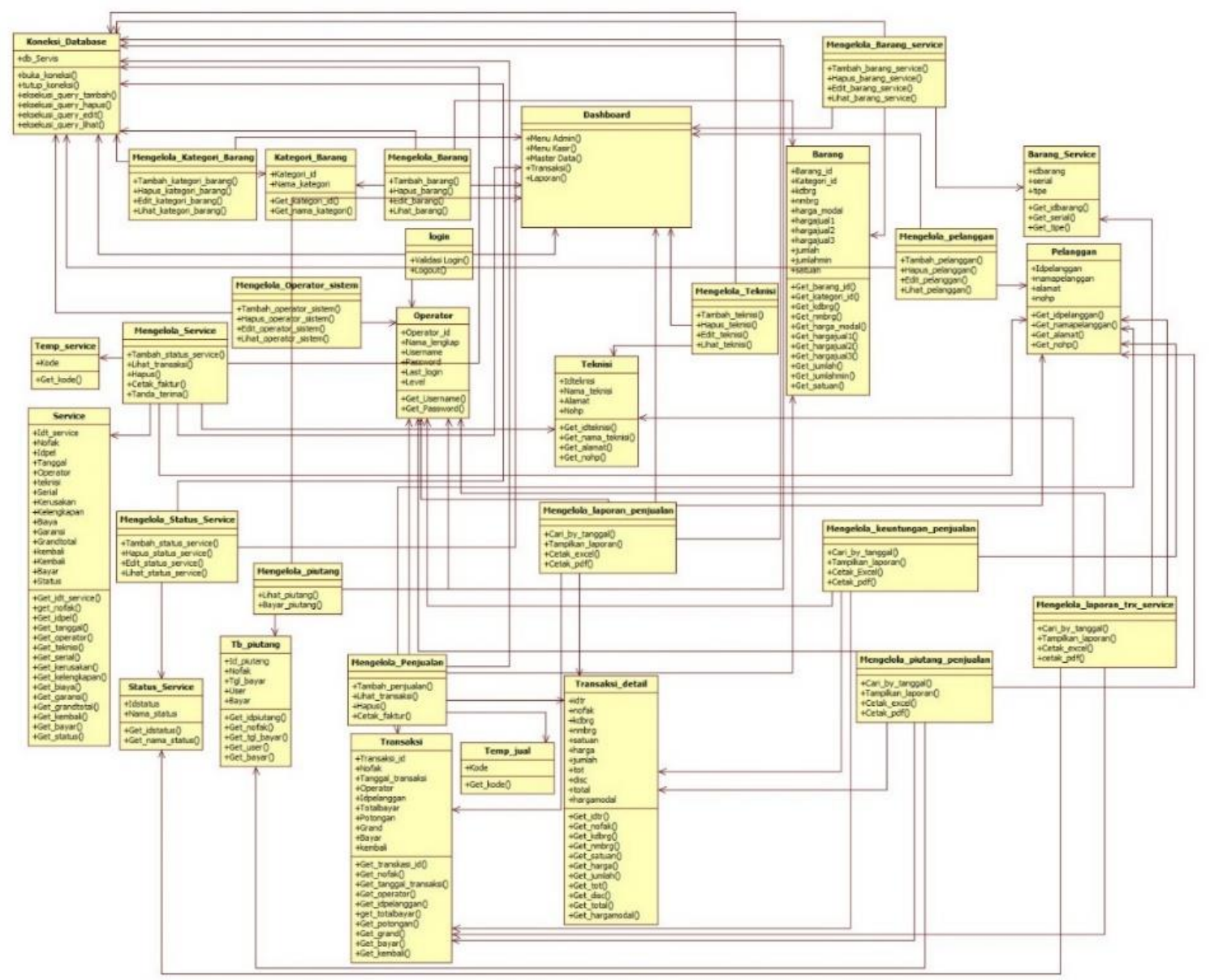

b. Prosedur Sistem

Gambar 3. Class Diagram

Tabel 3. Prosedur Sistem

\begin{tabular}{|c|c|c|}
\hline No & Prosedur & Aktivitas \\
\hline 1 & Login & $\begin{array}{l}\text { 1. Admin mengakses halaman web } \\
\text { 2. Admin memasukan username dan password } \\
\text { 3. Sistem akan membuka koneksi by database } \\
\text { 4. Sistem akan memvalidasi login } \\
\text { 5. Proses login akan menampilkan benar atau tidaknya validasi login dari } \\
\text { username dan password yang dimasukan } \\
\text { 6. Jika benar maka admin akan masuk ke halaman dashboard dan menu admin }\end{array}$ \\
\hline \multicolumn{3}{|c|}{ Menu Admin } \\
\hline 2 & $\begin{array}{l}\text { Kelola } \\
\text { Kategori } \\
\text { Barang }\end{array}$ & $\begin{array}{l}\text { Admin yang telah melakukan login akan masuk ke menu admin dimana dan } \\
\text { akses menu kategori barang, pada kelola kategori barang ini admin dapat } \\
\text { menambah, hapus, edit dan lihat data kategori barangyang terdapat dalam table } \\
\text { kategori barang }\end{array}$ \\
\hline 3 & $\begin{array}{l}\text { Kelola } \\
\text { Barang }\end{array}$ & $\begin{array}{l}\text { Admin yang telah melakukan login akan masuk ke menu admin dimana dan } \\
\text { akses menu barang, pada kelola kategori barang ini admin dapat menambah, } \\
\text { hapus, edit dan lihat data barang yang terdapat dalam table barang }\end{array}$ \\
\hline 4 & $\begin{array}{l}\text { Kelola } \\
\text { Barang } \\
\text { Service }\end{array}$ & $\begin{array}{l}\text { Admin yang telah melakukan login akan masuk ke menu admin dimana dan } \\
\text { akses menu barang Service, pada kelola barang service ini admin dapat } \\
\text { menambah, hapus, edit dan lihat data barang service yang terdapat dalam table } \\
\text { barang service }\end{array}$ \\
\hline
\end{tabular}




\begin{tabular}{|c|c|c|}
\hline No & Prosedur & $\begin{array}{c}\text { Aktivitas } \\
\end{array}$ \\
\hline 5 & $\begin{array}{l}\text { Kelola } \\
\text { Pelanggan }\end{array}$ & $\begin{array}{l}\text { Admin yang telah melakukan login akan masuk ke menu admin dimana dan } \\
\text { akses menu kelola pelanggan, pada kelola pelanggan ini admin dapat menambah, } \\
\text { hapus, edit dan lohat data pelanggan yang terdapat dalam table pelanggan }\end{array}$ \\
\hline 6 & $\begin{array}{l}\text { Kelola } \\
\text { Teknis }\end{array}$ & $\begin{array}{l}\text { Admin yang telah melakukan login akan masuk ke menu admin dimana dan } \\
\text { akses menu Teknisi, pada kelola Teknisi ini admin dapat menambah, hapus, edit } \\
\text { dan lihat data Teknisi yang terdapat dalam table teknisi. }\end{array}$ \\
\hline 7 & $\begin{array}{l}\text { Operator } \\
\text { Sistem }\end{array}$ & $\begin{array}{l}\text { Admin yang telah melakukan login akan masuk ke menu admin dimana dan } \\
\text { akses menu Operator Sistem, pada Operator sistem ini admin dapat menambah, } \\
\text { hapus, edit dan lihat data Operator yang terdapat dalam table Operator }\end{array}$ \\
\hline 8 & $\begin{array}{l}\text { Kelola } \\
\text { Status } \\
\text { Service }\end{array}$ & $\begin{array}{l}\text { Admin yang telah melakukan login akan masuk ke menu admin dimana dan } \\
\text { akses menu status service, pada kelola status service ini admin dapat menambah, } \\
\text { hapus, edit dan lihat data status service yang terdapat dalam table status service }\end{array}$ \\
\hline 9 & $\begin{array}{l}\text { Kelola } \\
\text { Penjualan }\end{array}$ & $\begin{array}{l}\text { Admin yang telah melakukan login akan masuk ke menu admin dimana dan } \\
\text { akses menu Penjualan, pada kelola penjualan ini admin dapat menambah, hapus, } \\
\text { edit dan lihat data penjualan yang terdapat dalam table transaksi, } \\
\text { transaksi_detail. Pada halaman ini juga admin dapat mencetak faktur dan tanda } \\
\text { terima. }\end{array}$ \\
\hline 10 & $\begin{array}{l}\text { Kelola } \\
\text { Transaksi } \\
\text { Service }\end{array}$ & $\begin{array}{l}\text { Admin yang telah melakukan login akan masuk ke menu admin dimana dan } \\
\text { akses menu service, pada kelola service ini admin dapat menambah, hapus, edit } \\
\text { dan lihat data service yang terdapat dalam table status service. Pada halaman ini } \\
\text { juga admin dapat mencetak faktur dan tanda terima }\end{array}$ \\
\hline 11 & $\begin{array}{l}\text { Kelola } \\
\text { Piutang }\end{array}$ & $\begin{array}{l}\text { Admin yang telah melakukan login akan masuk ke menu admin dimana dan } \\
\text { akses menu Piutang, pada kelola piutang ini admin dapat menambah data dengan } \\
\text { bayar piutang dan melihat data piutang yang terdapat dalam table Tb piutang }\end{array}$ \\
\hline 12 & $\begin{array}{l}\text { Kelola } \\
\text { Laporan } \\
\text { Penjualan }\end{array}$ & $\begin{array}{l}\text { Admin yang telah melakukan login akan masuk ke menu admin dimana dan } \\
\text { akses menu Laporan Penjualan, pada kelola laporan penjualan ini admin dapat } \\
\text { data berdasarkan tanggal. Pada halaman ini juga admin dapat mengkonvert ke } \\
\text { excel dan juga PDF. }\end{array}$ \\
\hline 13 & $\begin{array}{l}\text { Laporan } \\
\text { Transaksi } \\
\text { Service }\end{array}$ & $\begin{array}{l}\text { Admin yang telah melakukan login akan masuk ke menu admin dimana dan } \\
\text { akses menu Laporan transaksi service, pada kelola laporan transaksi service ini } \\
\text { admin dapat data berdasarkan tanggal. Pada halaman ini juga admin dapat } \\
\text { mengkonvert ke excel dan juga PDF }\end{array}$ \\
\hline 14 & $\begin{array}{l}\text { Laporan } \\
\text { Keuntungan } \\
\text { Penjualan }\end{array}$ & $\begin{array}{l}\text { Admin yang telah melakukan login akan masuk ke menu admin dimana dan } \\
\text { akses menu Laporan Keuntungan penjualan, pada kelola laporan Keuntungan } \\
\text { penjualan ini admin dapat data berdasarkan tanggal. Pada halaman ini juga } \\
\text { admin dapat mengkonvert ke excel dan juga PDF }\end{array}$ \\
\hline 15 & $\begin{array}{l}\text { Kelola } \\
\text { Laporan } \\
\text { Piutang }\end{array}$ & $\begin{array}{l}\text { Admin yang telah melakukan login akan masuk ke menu admin dimana dan } \\
\text { akses menu Laporan piutang, pada kelola laporan piutang ini admin dapat data } \\
\text { berdasarkan tanggal. Pada halaman ini juga admin dapat mengkonvert ke excel } \\
\text { dan juga PDF }\end{array}$ \\
\hline \multicolumn{3}{|c|}{ Menu Kasir } \\
\hline 16 & $\begin{array}{l}\text { Kelola } \\
\text { Kategori } \\
\text { Barang }\end{array}$ & $\begin{array}{l}\text { Kasir yang telah melakukan login akan masuk ke menu Kasir dimana dan akses } \\
\text { menu kategori barang, pada kelola kategori barang ini Kasir dapat menambah, } \\
\text { dan lihat data kategori barangyang terdapat dalam table kategori barang }\end{array}$ \\
\hline 17 & $\begin{array}{l}\text { Kelola } \\
\text { Barang }\end{array}$ & $\begin{array}{l}\text { Kasir yang telah melakukan login akan masuk ke menu Kasir dimana dan akses } \\
\text { menu barang, pada kelola kategori barang ini Kasir dapat menambah dan lihat } \\
\text { data barang yang terdapat dalam table barang }\end{array}$ \\
\hline 18 & $\begin{array}{l}\text { Kelola } \\
\text { Barang } \\
\text { Service }\end{array}$ & $\begin{array}{l}\text { Kasir yang telah melakukan login akan masuk ke menu Kasir dimana dan akses } \\
\text { menu barang Service, pada kelola barang service ini Kasir dapat menambah dan } \\
\text { lihat data barang service yang terdapat dalam table barang service }\end{array}$ \\
\hline
\end{tabular}




\begin{tabular}{|c|l|l|}
\hline No & Prosedur & \multicolumn{1}{c|}{ Aktivitas } \\
\hline 19 & $\begin{array}{l}\text { Kelola } \\
\text { Pelanggan }\end{array}$ & $\begin{array}{l}\text { Kasir yang telah melakukan login akan masuk ke menu Kasir dimana dan akses } \\
\text { menu kelola pelanggan, pada kelola pelanggan ini Kasir dapat menambah dan } \\
\text { lohat data pelanggan yang terdapat dalam table pelanggan. }\end{array}$ \\
\hline 20 & $\begin{array}{l}\text { Kelola } \\
\text { Status } \\
\text { Service }\end{array}$ & $\begin{array}{l}\text { Kasir yang telah melakukan login akan masuk ke menu Kasir dimana dan akses } \\
\text { menu status service, pada kelola status service ini Kasir dapat menambah dan } \\
\text { lihat data status service yang terdapat dalam table status service. }\end{array}$ \\
\hline 21 & $\begin{array}{l}\text { Kelola } \\
\text { Penjualan }\end{array}$ & $\begin{array}{l}\text { Kasir yang telah melakukan login akan masuk ke menu Kasir dimana dan akses } \\
\text { menu Penjualan, pada kelola penjualan ini Kasir dapat menambah dan lihat data } \\
\text { penjualan yang terdapat dalam table transaksi, transaksi_detail. Pada halaman } \\
\text { ini juga Kasir dapat mencetak faktur dan tanda terima }\end{array}$ \\
\hline 22 & $\begin{array}{l}\text { Kelola } \\
\text { Transaksi }\end{array}$ & $\begin{array}{l}\text { Kasir yang telah melakukan login akan masuk ke menu Kasir dimana dan akses } \\
\text { menu service, pada kelola service ini Kasir dapat menambah dan lihat data } \\
\text { service yang terdapat dalam table status service. Pada halaman ini juga Kasir } \\
\text { dapat mencetak faktur dan tanda terima }\end{array}$ \\
\hline 23 & $\begin{array}{l}\text { Kelola } \\
\text { Piutang }\end{array}$ & $\begin{array}{l}\text { Kasir yang telah melakukan login akan masuk ke menu admin dimana dan akses } \\
\text { menu Piutang, pada kelola piutang ini admin dapat menambah data dengan bayar } \\
\text { piutang dan melihat data piutang yang terdapat dalam table Tb piutang }\end{array}$ \\
\hline
\end{tabular}

\section{c. Hasil Penelitian}

Aplikasi ini dibuat menggunakan bahasa pemrograman PHP dengan Framework Codeigniter dan Database Mysql dan desain interface mengunakan Framework Bootstrap. Menghasikan aplikasi manajemen servis dan penjualan di Sumedang Laptop yang dapat berjalan dengan baik di Browser Chrome dan Firefox.

Adapun struktur menu dari aplikasi ini adalah :

a. Halaman Login

b. Halaman Dashboard (admin \& Teknisi)

c. Halaman Master Data

1. Kategori Barang

2. Data Barang

3. Data Barang Service

4. Data Pelanggan

5. Data Teknisi

6. Operator Sistem

7. Status Service

d. Transaksi

1. Penjualan

2. Service

3. Piutang

e. Laporan

1. Laporan Penjualan

2. Laporan Service

3. Laporan Keuntungan

4. Laporan Piutang

f. Keluar

Dari hasil Analisa dan rancangan system berdasarkan aktifitas, menghasilakan sebuah system aplikasi manajemen servis dan penjualan laptop, hasil sebagai berikut : 


\section{Halaman Login}

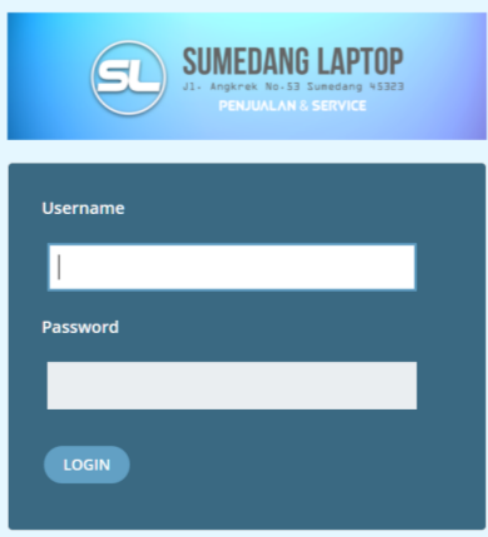

Aplikasi Penjualan dan Service Komputer () david 2017

Gambar 4. Halaman Login

\section{Halaman Dashboard}

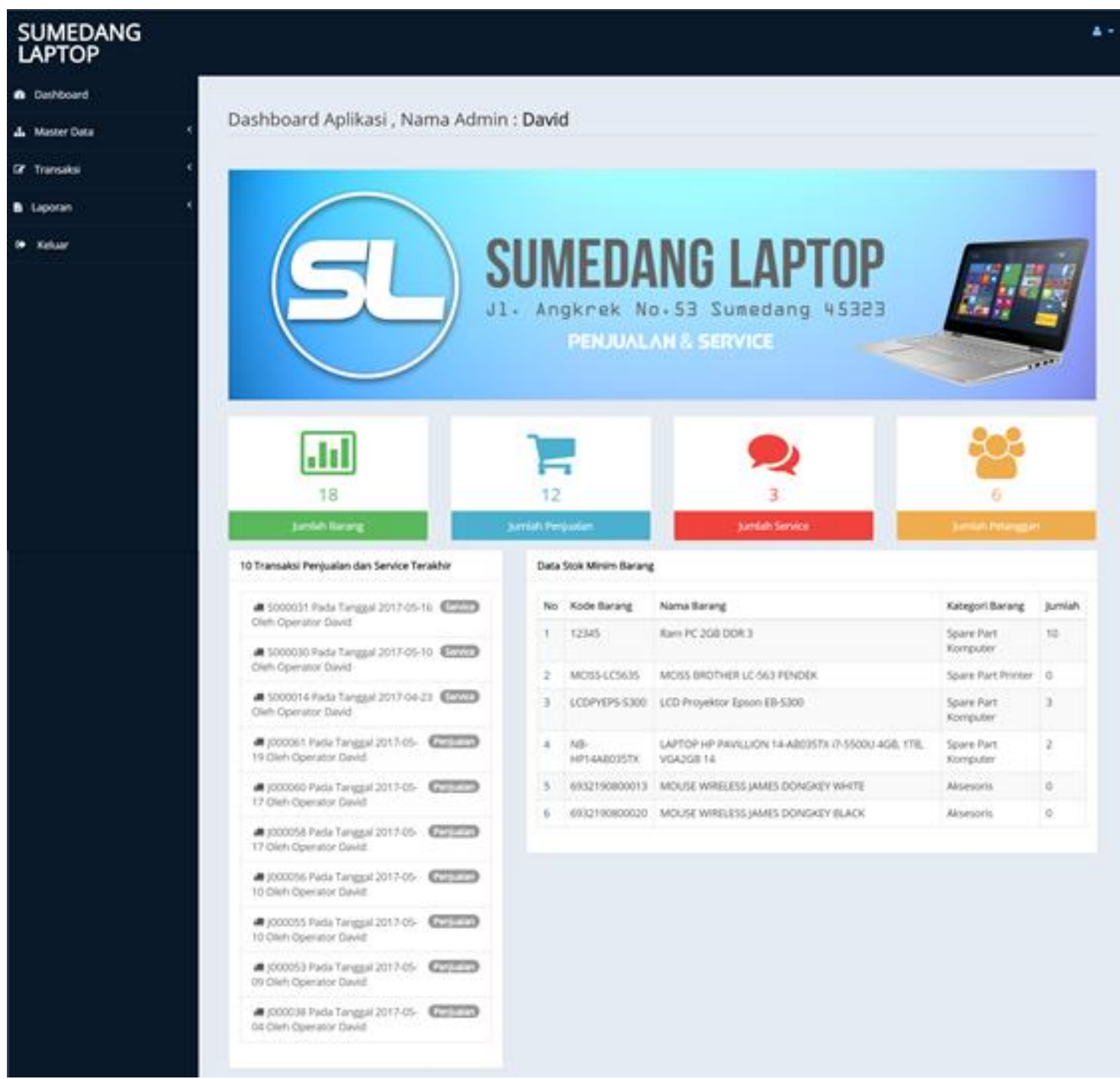

Gambar 5. Halaman Dashboard 
3. Master data (kategori barang)

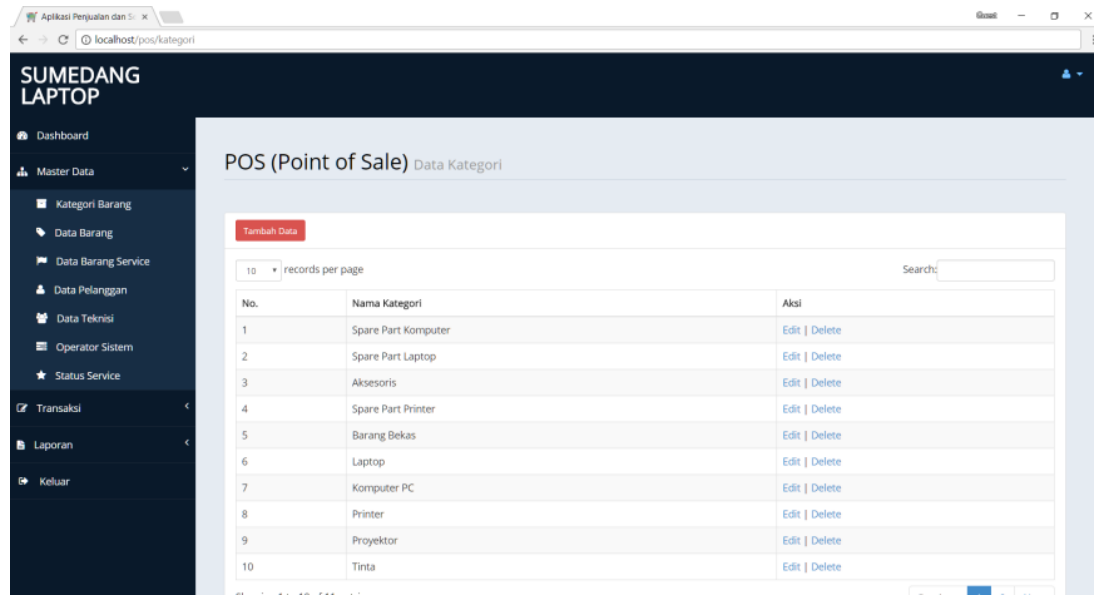

Gambar 6. Halaman Master Data Kategori barang

\section{Master Data - Data Barang}

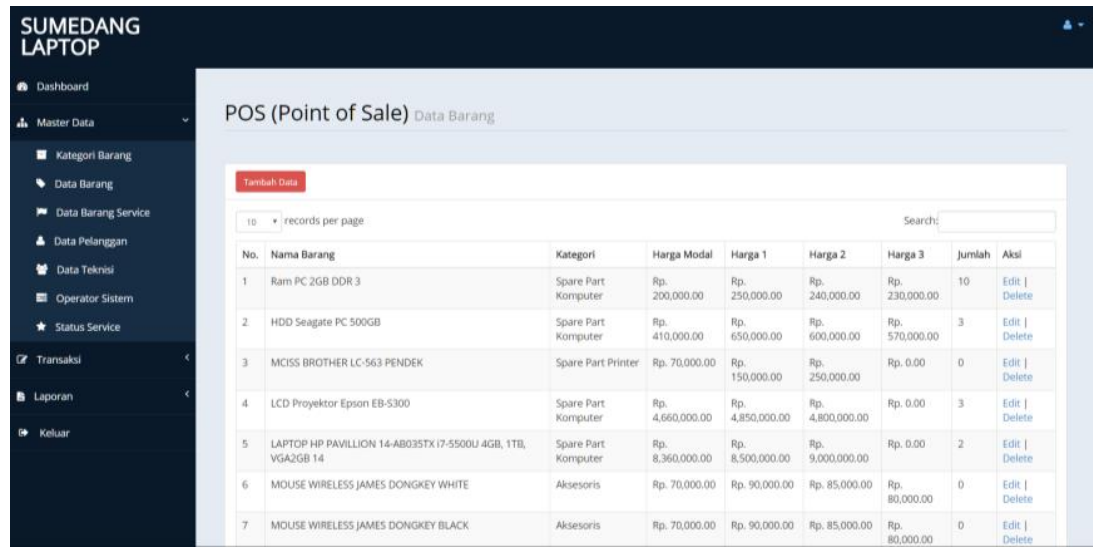

Gambar 7. Halaman Master Data Barang

5. Master Data - Data Barang Service

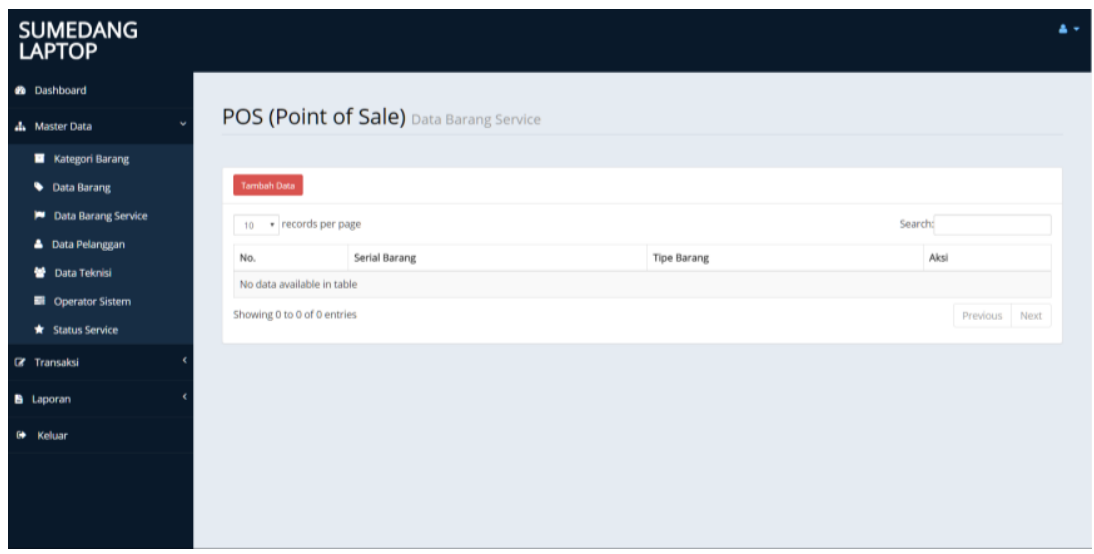

Gambar 8. Halaman Master Data Barang Service 
6. Master Data - Data Pelanggan

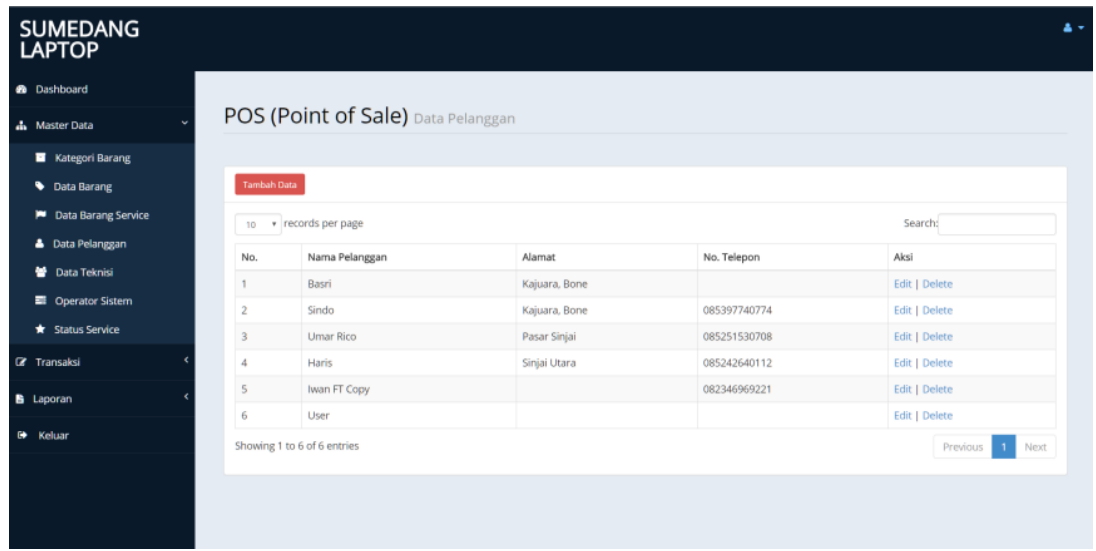

Gambar 9. Halaman Master Data Pelanggan

7. Master Data - Data Teknisi

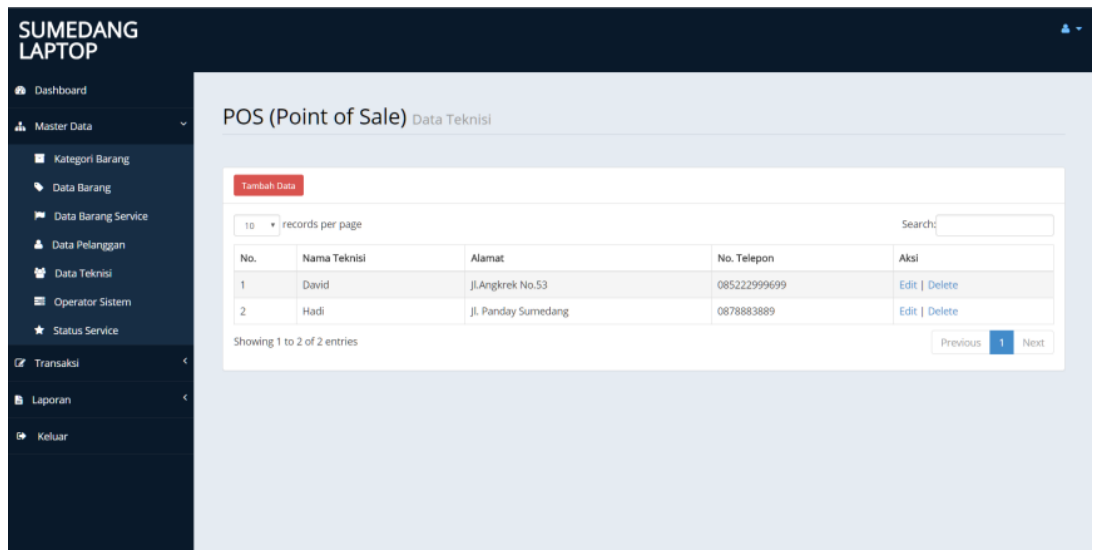

Gambar 10. Halaman Master Data Teknisi

8. Master Data - Operator Sistem

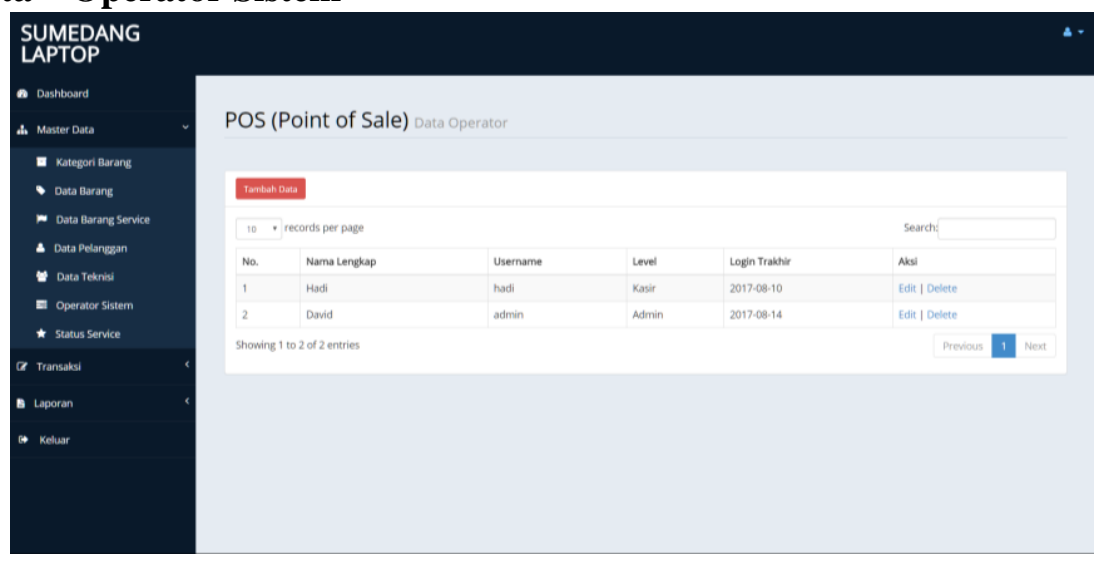

Gambar 11. Halaman Master Data Operator Sistem 
9. Master Data - Status Service

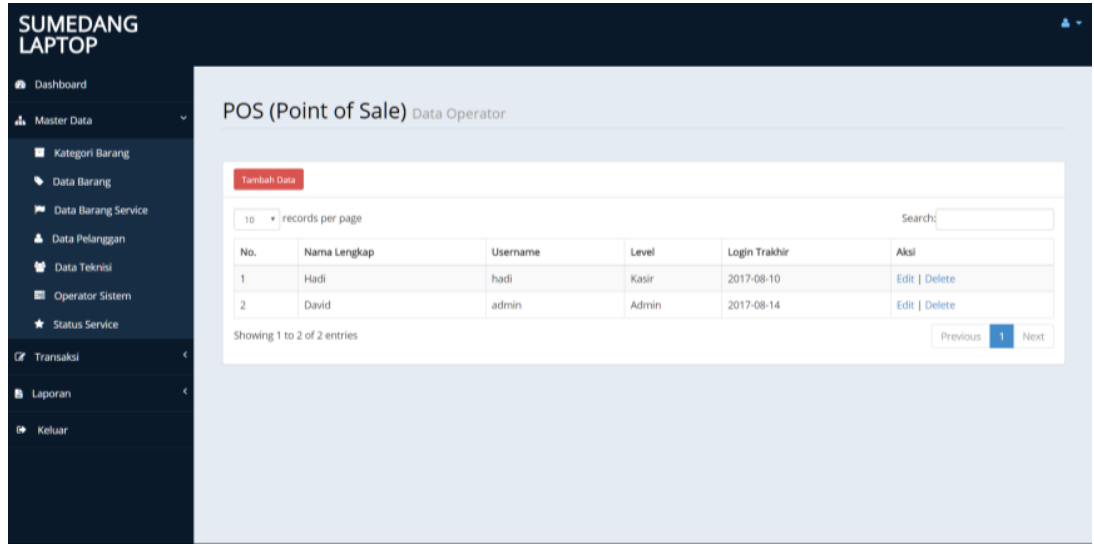

Gambar 12. Halaman Master Data Status Service

10. Transaksi- Penjualan

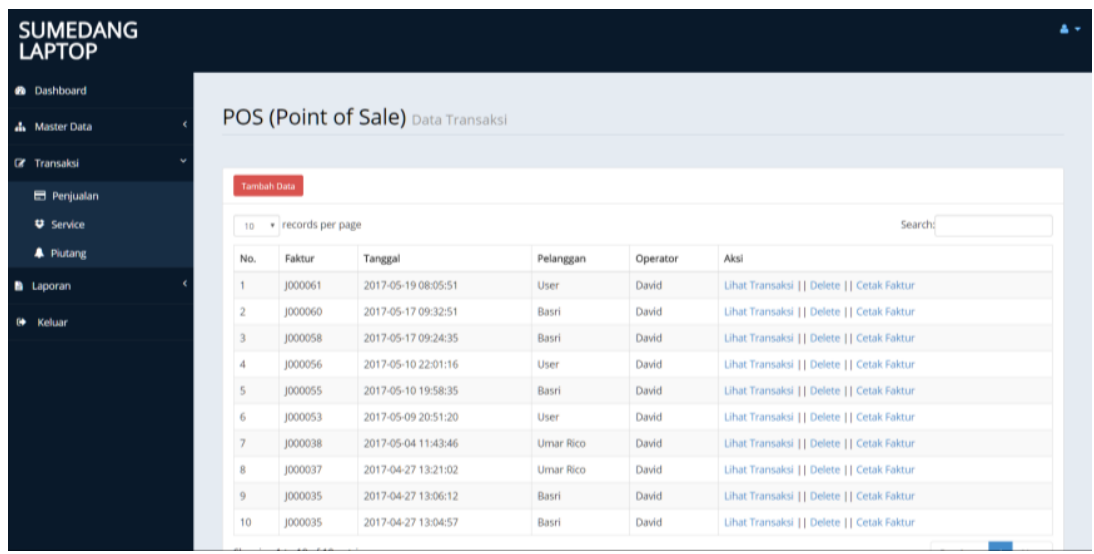

Gambar 13. Halaman Transaksi Penjualan

11. Transaksi - Service

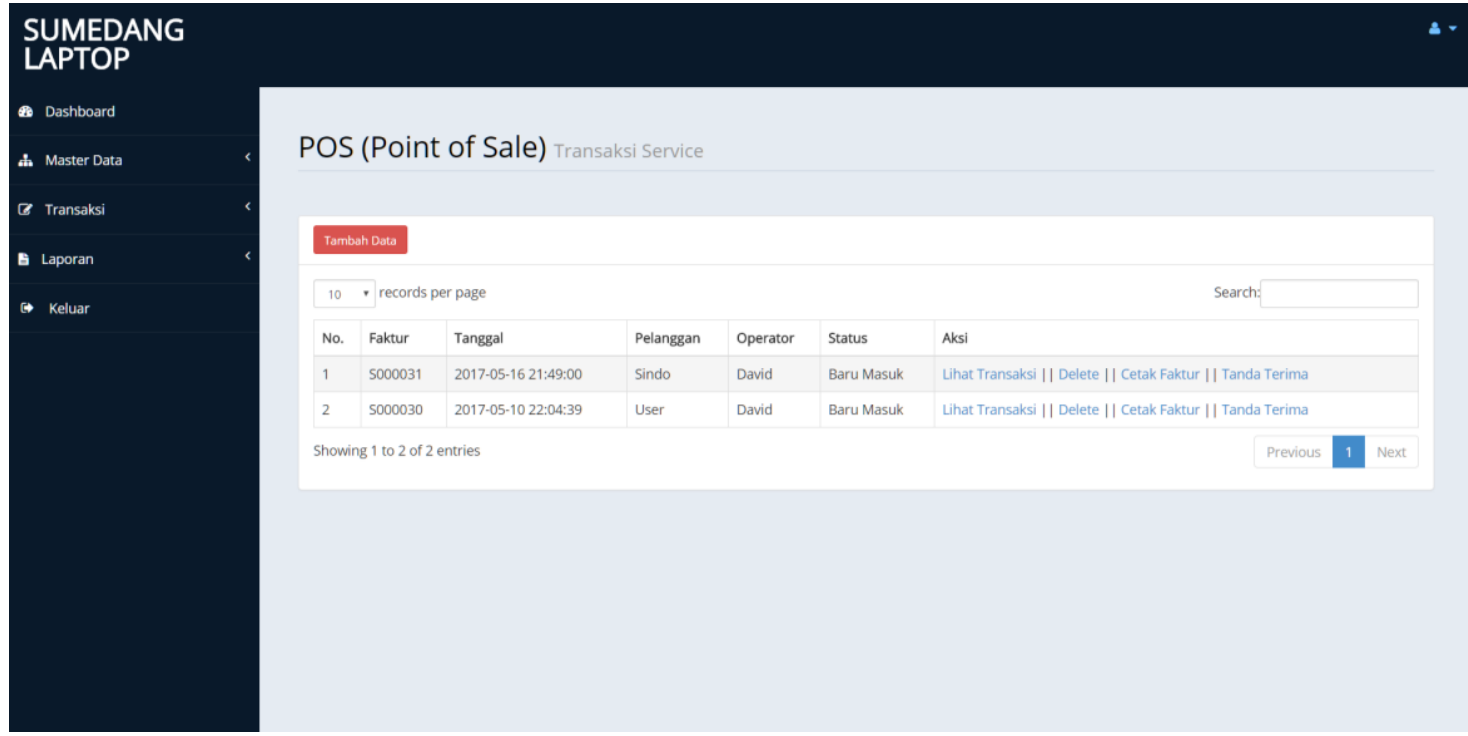

Gambar 14. Halaman Transaksi Service 


\section{Transaksi - Piutang}

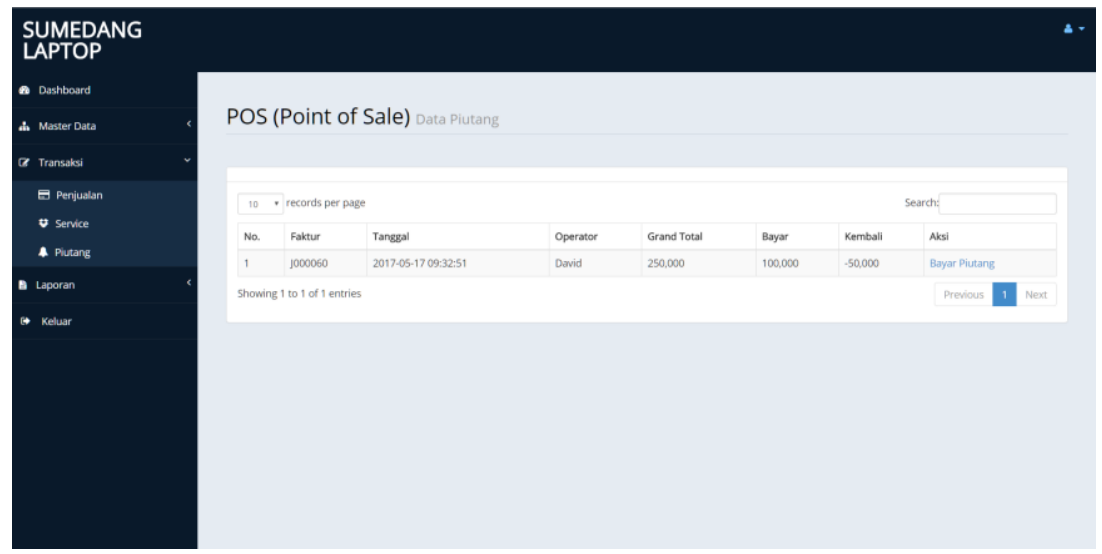

Gambar 15. Halaman Transaksi Piutang

\section{Laporan}

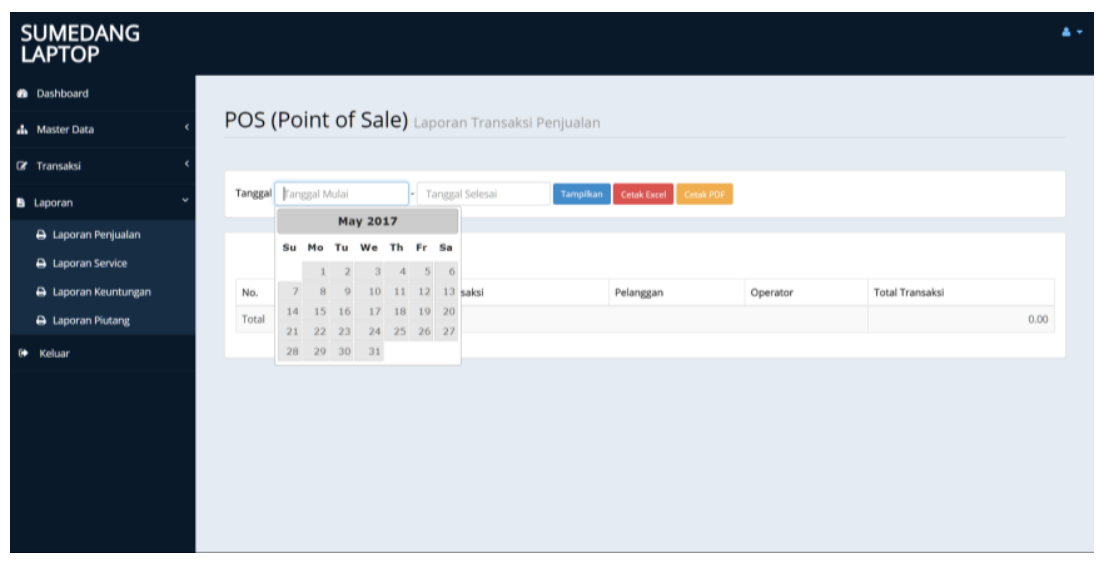

Gambar 16. Halaman Laporan

\section{d. Pengujian}

Berikut hasil pengujian menggunakan metode Blackbox testing :

Tabel 4. Hasil Pengujian

\begin{tabular}{|c|c|c|c|}
\hline No & Materi Yang Di Uji & Yang Diharapkan & Hasil Pengujian \\
\hline 1 & Dashboard & Menampilkan data statistik & $\mathrm{Ok}$ \\
\hline \multirow[t]{8}{*}{2} & Halaman Master Data & & \\
\hline & Kategori Barang & Create,Read,Update,Delete & $\mathrm{Ok}$ \\
\hline & Data Barang & Create,Read,Update,Delete & Ok \\
\hline & Data Barang Service & Create,Read,Update,Delete & Ok \\
\hline & Data Pelanggan & Create,Read,Update,Delete & Ok \\
\hline & Data Teknisi & Create,Read,Update,Delete & Ok \\
\hline & Operator Sistem & Create,Read,Update,Delete & Ok \\
\hline & Status Service & Create,Read,Update,Delete & $\mathrm{Ok}$ \\
\hline \multirow[t]{4}{*}{3} & Tarnsaksi & & \\
\hline & Penjualan & Create,Read,Update,Delete & $\mathrm{Ok}$ \\
\hline & Service & Create,Read,Update,Delete & Ok \\
\hline & Piutang & Create,Read,Update,Delete & Ok \\
\hline \multirow[t]{3}{*}{4} & Laporan & & \\
\hline & Laporan Penjualan & Create,Read,Update,Delete & Ok \\
\hline & Laporan Service & Create,Read,Update,Delete & $\mathrm{Ok}$ \\
\hline
\end{tabular}




\begin{tabular}{|c|l|c|c|}
\hline No & \multicolumn{1}{|c|}{ Materi Yang Di Uji } & Yang Diharapkan & Hasil Pengujian \\
\hline \multirow{2}{*}{} & Laporan Piutang & Create,Read,Update,Delete & Ok \\
\cline { 2 - 4 } & Laporan Keuntungan & Create,Read,Update,Delete & Ok \\
\hline 5 & Keluar & Keluar Aplikasi & Ok \\
\hline
\end{tabular}

\section{Conclusion}

Aplikasi manajemen servis dan penjualan dibuat menggunakan bahasa pemrograman PHP dengan framework Codeigniter dan database Mysql yang dipadukan dengan metode Prototyping dan pendekatan menggunakan UML menghasilkan aplikasi yang dapat membantu pencatatan dan tracking status laptop yang sedang diservis hingga laporan keuangan dari penjualan laptop di Sumedang Laptop.

\section{References}

[1]. Azhar Susanto. 2013. Sistem Informasi Akuntansi. Bandung: Lingga Jaya.

[2]. Eko Didik Widianto, 2012. Pemodelan Sistem dengan UML. http://didik.blog.undip.ac.id/2012/03/06/kuliah-tsk-612-sistem-embedded-terdistribusi

[3]. Jogiyanto.2009.Analisis dan Desain Sistem Informasi.Yogyakarta: Andi.

[4]. Sutarman.2009.Pengantar Teknologi Informasi.Jakarta: Sinar Grafika Offset

[5]. Tekno Kompas, diperoleh 14 Agustus 2017, http://tekno.kompas.com/read/2017/03/15/16483787/asus.klaim.kuasai.pasar.laptop.indonesia

[6]. International Data Corporation (IDC), www.idc.com, diperoleh14 Agustus 2017 